\title{
ENHANCING EFL LEARNERS' MOTIVATION THROUGH SONGS
}

\author{
Reza Anggriyashati Adara*, Muhammad Taufik \\ Universitas Islam 45 Bekasi, Indonesia \\ (reza.adara@gmail.com) \\ Received: $11^{\text {th }}$ Sept 2020; Revised: $09^{\text {th }}$ Dec 2020; Accepted: $25^{\text {th }}$ Dec 2020
}

\begin{abstract}
Improving learners' motivation is an essential task for teachers because it can maintain learners' interest in learning. This is why teachers employ numerous motivational strategies in order to enhance learners' motivation. One of the strategies that can enhance learners' motivation is using songs in English classrooms. The present study aims to analyse the effects of using songs in EFL classrooms on EFL learners' motivation. The study used an experimental method by dividing the respondents into two groups: the experimental and control classes. While the control class was taught English conventionally, the experimental class lessons were integrated with English songs. Furthermore, a set of questionnaires and semi-structured interviews were administered in order to obtain the data. The findings suggest that songs seem to have positive effects on EFL learners' motivation. Besides, using songs in EFL classrooms helps learners absorb new vocabulary and make English lessons more engaging. Thus, English teachers need to consider using English songs in their classrooms to improve learners' motivation. Nevertheless, songs need to be suited to the learners' level of English, age, and characteristics of the lessons.
\end{abstract}

Key Words: EFL; learners' motivation; motivational strategies; songs

\section{ABSTRAK}

Meningkatkan motivasi siswa adalah tugas penting bagi guru karena hal itu bisa meningkatkan minat siswa dalam belajar. Hal itu yang membuat guru menerapkan berbagai strategi motivasional demi meningkatkan motivasi siswa. Salah satu strategi yang dapat digunakan untuk meningkatkan motivasi siswa adalah menggunakan lagu-lagu di kelas-kelas bahasa Inggris. Penelitian ini bertujuan untuk menganalisis efek-efek lagu dalam peningkatan motivasi di kelas-kelas bahasa Inggris. Penelitian ini menggunakan metode eksperimental dengan membagi responden ke dalam dua grup: eksperimental dan kontrol. Kelas kontrol belajar bahasa Inggris secara konvensional sedangkan kelas eksperimental belajar bahasa Inggris dengan pelajaran yang diintegrasikan dengan lagu. Selain itu penelitian ini menggunakan kuesioner dan wawancara semi terstruktur untuk mendapatkan hasilnya. Penelitian ini mengindikasikan lagu dapat memotivasi siswa untuk belajar bahasa Inggris dan mendapatkan kosakata baru. Oleh karena itu, guru harus mempertimbangkan penggunaan lagu dalam kelaskelas bahasa Inggris untuk meningkatkan motivasi siswa. Namun, penggunaan lagu perlu disesuaikan dengan level kemampuan bahasa Inggris, usia dan karakteristik pelajaran.

Kata Kunci: EFL; lagu; strategi motivasi; motivasi siswa

How to Cite: Adara Reza A., Taufik M. (2020). Enhancing EFL Learners' Motivation Through Songs. IJEE (Indonesian Journal of English Education), 7(2), 189-200. doi:10.17321/ijee.v7i2.17321

\footnotetext{
* Corresponding author

IJEE (Indonesian Journal of English Education), 7 (2), 2020, 189-200

P-ISSN: 2356-1777, E-ISSN: 2443-0390 | DOI: http://doi.org/10.15408/ijee.v7i1.17321

This is an open access article under CC-BY-SA license (https://creativecommons.org/licenses/by-sa/4.0/)
} 


\section{INTRODUCTION}

The mastery of the English language is undoubtedly vital in Indonesia due to the position of English as a global language. Crystal (2003) argues that English has been used by people from various socio-economic, education, and cultures. Besides, Karyanto (2019) remarks that there are 400 million native English speakers and 2 million English language learners who study it either as a second or foreign language. The rapidly changing world makes it essential for people to adopt English to communicate with people from different countries (Adara, 2019; Graddol, 2006). Mastering English may help people communicate with people from different countries, resulting in better communication in various fields such as economy, politics, education, etc. As part of global citizenship, Indonesians need to be able to communicate in English.

Furthermore, Coleman (2011) reported that the Ministry of Education of Indonesia had introduced English as a medium of instruction in several school subjects in Indonesia due to its importance. Similarly, it has been reported that English is one of the field studies in Indonesian schools (Jalal \& Musthafa, 2001). The above points suggest the importance of the English language in Indonesia because it is used by many people globally and helps communication in the global arena.

Related to the above paragraph, maintaining learners' motivation is vital in language learning processes. In this regard, motivation can be defined as an internal need that makes someone eager to achieve something (Harmer, 2001; Huang, 2007). Motivation helps to maintain learners 'interest during the language learning process (Dörnyei, 2005; Dornyei \& Csizér, 2002). Motivation can construe either the success or the failure of any complex task (Brown \& Lee, 2015). In this sense, motivation can be regarded as an important factor determining the success of learners' language learning process. Thus, analysing motivation seems imperative because it will provide more information on sustaining learners' interests (Carrió-Pastor \& Mestre, 2014). The above points suggest the importance of motivation in the language learning process.

Teachers can use motivational strategies to improve learners' motivation. One of the crucial factors that can affect learners' motivation is a teacher. In his study on motivation of a group of junior high school students in Indonesia's rural area, Lamb (2007) showed that teachers could affect learners' motivation. Several studies also found similar results (Khazaie \& 
Mesbah, 2014; Poornima et al., 2016). Teachers could influence learners' motivation through motivational strategies that refer to teachers' techniques to develop positive attitudes toward language learning (Dörnyei, 2001; 2003). Teachers' provision of motivational strategies is important for language learning processes (Chambers, 1999; Cheng \& Dörnyei, 2007; Fives \& Manning, 2005). Teachers can provide meaningful tasks or activities as motivational strategies for their students. Numerous studies have shown a positive correlation between tasks and students' motivation (Cheng \& Dörnyei, 2007; Dornyei \& Csizér, 2002). People are more motivated to do something if they are interested in it (Cheng \& Dörnyei, 2007). Thus, it seems crucial for teachers to provide exciting activities or tasks that can be suitable motivational strategies for their students.

One of the motivational strategies that teachers can do in language classrooms is using songs. Faliyanti (2017) remarks that songs can be an alternative medium to create an engaging learning atmosphere. In this sense, songs may minimise the boredom in the language classroom because it gives learners a rest from textbooks or exercise books. Furthermore, White (2007) states that using songs in the class will improve learners' musical aptitude and improve learning processes as a whole. A study by Chen and Chen (2009) investigated the effects of songs on motivation and competency of a group of learners in China and found that songs positively impact the participants' motivation.

Nevertheless, a lack of studies specifically investigates the effects of a song in EFL classrooms in the Indonesian context. Analysing the effects of songs on EFL learners' motivation will help provide knowledge regarding factors that affect learners' motivation. Thus, the present study aims to analyse the effects of songs on EFL learners' motivation. The present study is guided by the following research question: What are the effects of songs on EFL learners' motivation?.

\section{METHOD}

\section{Research design}

The present study applied an experimental method as it gives treatment to the respondents for six sessions in three consecutive weeks. The sampling method was convenience sampling. The respondents of the present study were 66 junior high school students in Cibarusah, Indonesia. The respondents were divided into two groups: experimental and control classes. While the control 
class was given a conventional teaching method, the experimental class lessons were integrated with songs. Each lesson in the experimental class started with a song that the students watched through a projector. Next, the experimental class students were encouraged to discuss the meanings of lyrics with their classmates. The use of a dictionary was also encouraged. The songs were usually related to individual lessons. Before the class ended, teachers played another song that needed to be discussed by students.

\section{Data collection and analysis}

The present study used a mixedmethod approach. The present study used a set of questionnaires adapted from Zafarghandi and Jodai's (2012) study on the attitudes and motivation of a group of English learners in an Iranian university. The questionnaire consists of 18 items with a fourresponse Likert scale (totally agree, agree, disagree, totally disagree). The questionnaires aimed to measure four variables; learners' attitudes toward the English language, learners' attitudes toward English speaking communities, instrumentality, and learners' attitudes toward English language learning. The questionnaires are written in Bahasa Indonesia so that the respondents will understand them better. To ensure the questionnaires' validity, a pilot study was conducted and resulted in Cronbach Alpha $>0,65 . \quad$ The questionnaires are distributed before and after the treatment of both classes. In addition to the questionnaires, the present study conducted interviews with four respondents to provide more insights into the effects of songs on EFL learners' motivation.

Due to the nature of the present study, data were analysed differently. While the quantitative data was analysed using SPSS (Statistical Package for the Social Science), the qualitative data was analysed through coding. The interview results were transcribed before coded into several categories. Thus, obtained data were triangulated with existing theories and results of related prior studies.

\section{FINDINGS AND DISCUSSION}

\section{Findings}

To provide a better organisation, the findings are discussed based on four variables in the questionnaire. 
Table 1. Learners' attitudes toward the English language.

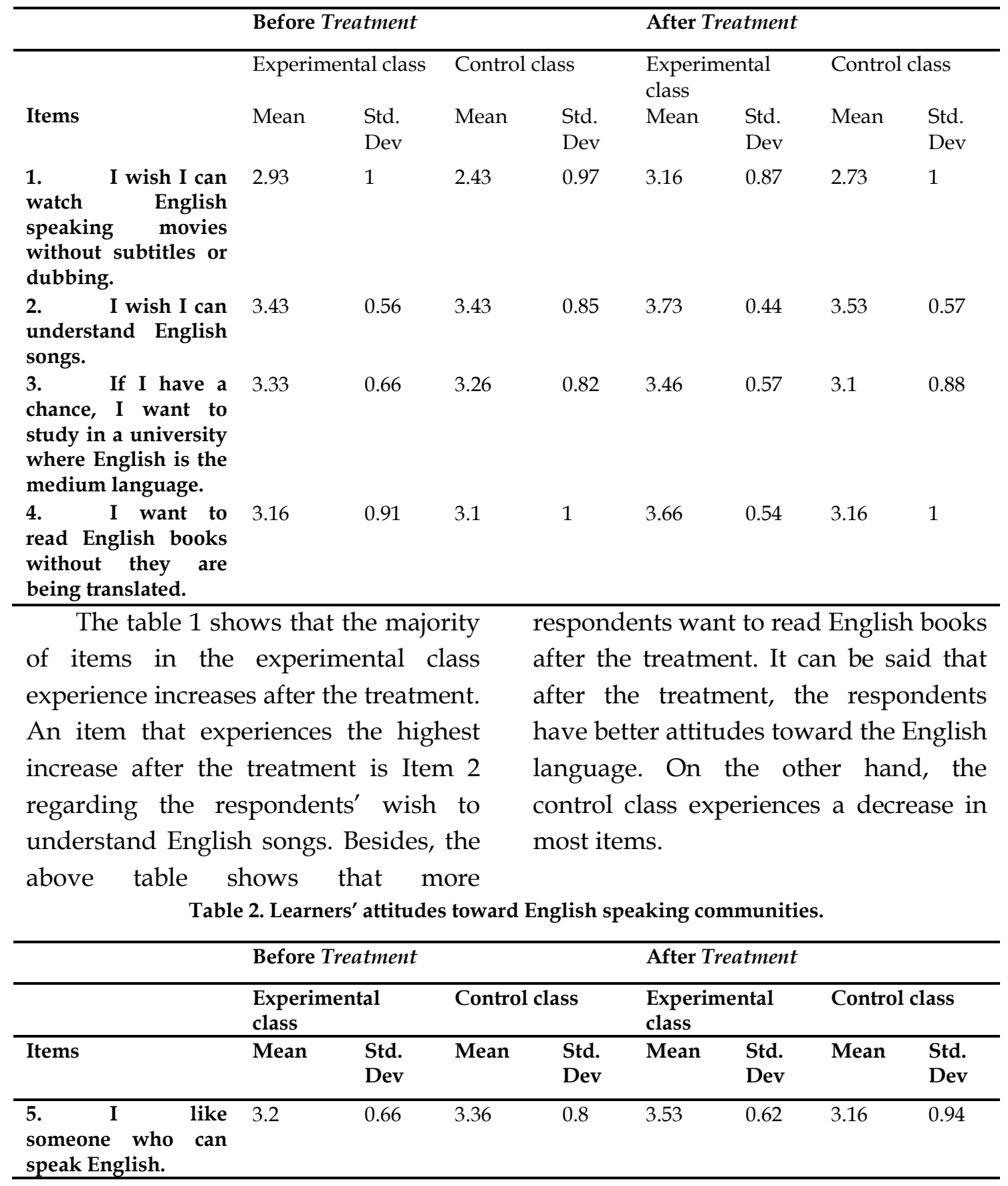




\begin{tabular}{|c|c|c|c|c|c|c|c|c|}
\hline \multirow[b]{3}{*}{ Items } & \multicolumn{4}{|c|}{ Before Treatment } & \multicolumn{4}{|c|}{ After Treatment } \\
\hline & \multicolumn{2}{|c|}{$\begin{array}{l}\text { Experimental } \\
\text { class }\end{array}$} & \multicolumn{2}{|c|}{ Control class } & \multicolumn{2}{|c|}{$\begin{array}{l}\text { Experimental } \\
\text { class }\end{array}$} & \multicolumn{2}{|c|}{ Control class } \\
\hline & Mean & $\begin{array}{l}\text { Std. } \\
\text { Dev }\end{array}$ & Mean & $\begin{array}{l}\text { Std. } \\
\text { Dev }\end{array}$ & Mean & $\begin{array}{l}\text { Std. } \\
\text { Dev }\end{array}$ & Mean & $\begin{array}{l}\text { Std. } \\
\text { Dev }\end{array}$ \\
\hline $\begin{array}{lr}6 . & \text { I want } \\
\text { improve my } & \text { English } \\
\text { skills } & \text { to } \\
\text { communicate } & \text { with } \\
\text { foreigners } & \text { who } \\
\text { cannot } & \text { speak } \\
\text { Indonesian. } & \end{array}$ & 3.53 & 0.57 & 3.4 & 0.89 & 3.9 & 0.3 & 3.7 & 0.53 \\
\hline $\begin{array}{l}7 . \quad \text { I want to } \\
\text { live or visit English } \\
\text { speaking countries. }\end{array}$ & 3.36 & 0.71 & 3.46 & 0.86 & 3.76 & 0.56 & 3.23 & 0.72 \\
\hline $\begin{array}{l}8 . \quad \text { If I meet a } \\
\text { foreigner, I will try } \\
\text { to speak English. }\end{array}$ & 3.13 & 0.57 & 3.06 & 0.86 & 3.46 & 0.62 & 4 & 0.67 \\
\hline
\end{tabular}

The table 2 shows that the majority of items in the experimental class experience increases after the treatment. An item that experiences the most salient item in the experimental class after the treatment is Item 6. It shows that most experimental class respondents are more motivated to improve their English skills after the treatment. A similar phenomenon happens to the control class, which increases Item 6 and Item 8 after the treatment. Nevertheless, the table shows Item 5 and Item 7 in the control class experience decreases after the treatment. The above table indicates that although both classes seem to have positive attitudes toward English speaking communities, the experimental class show more improvements.

Table 3. Instrumentality

\begin{tabular}{lllllllll}
\hline & \multicolumn{3}{l}{ Before Treatment } & & \multicolumn{3}{l}{ After Treatment } \\
\hline & $\begin{array}{l}\text { Experimental } \\
\text { class }\end{array}$ & Control class & \multicolumn{2}{l}{$\begin{array}{l}\text { Experimental } \\
\text { class }\end{array}$} & Control class \\
\hline Items & Mean & $\begin{array}{l}\text { Std. } \\
\text { Dev }\end{array}$ & Mean & $\begin{array}{l}\text { Std. } \\
\text { Dev }\end{array}$ & Mean & $\begin{array}{l}\text { Std. } \\
\text { Dev }\end{array}$ & Mean & $\begin{array}{l}\text { Std. } \\
\text { Dev }\end{array}$ \\
\hline $\begin{array}{l}\text { 9. I want to } \\
\text { learn English to get a } \\
\text { better job } \\
\text { opportunity. }\end{array}$ & & 0.62 & 3.46 & 0.85 & 3.76 & 0.43 & 3.66 & 0.54 \\
\end{tabular}




\begin{tabular}{|c|c|c|c|c|c|c|c|c|}
\hline \multirow[b]{3}{*}{ Items } & \multicolumn{4}{|c|}{ Before Treatment } & \multicolumn{4}{|c|}{ After Treatment } \\
\hline & \multicolumn{2}{|c|}{$\begin{array}{l}\text { Experimental } \\
\text { class }\end{array}$} & \multicolumn{2}{|c|}{ Control class } & \multicolumn{2}{|c|}{$\begin{array}{l}\text { Experimental } \\
\text { class }\end{array}$} & \multicolumn{2}{|c|}{ Control class } \\
\hline & Mean & $\begin{array}{l}\text { Std. } \\
\text { Dev }\end{array}$ & Mean & $\begin{array}{l}\text { Std. } \\
\text { Dev }\end{array}$ & Mean & $\begin{array}{l}\text { Std. } \\
\text { Dev }\end{array}$ & Mean & $\begin{array}{l}\text { Std. } \\
\text { Dev }\end{array}$ \\
\hline $\begin{array}{l}\text { 10. English } \\
\text { skills will provide } \\
\text { me with a better } \\
\text { salary. }\end{array}$ & 2.83 & 0.69 & 3.26 & 0.87 & 3.33 & 0.66 & 3.16 & 0.87 \\
\hline $\begin{array}{l}\text { 11. I want to } \\
\text { learn } \\
\text { because I want to } \\
\text { have better scores in } \\
\text { the exams. }\end{array}$ & 3.36 & 0.76 & 3.5 & 0.77 & 3.76 & 0.62 & 3.56 & 0.72 \\
\hline $\begin{array}{l}\text { 12. I want to } \\
\text { learn } \\
\text { because I want to } \\
\text { communicate with } \\
\text { English speaking } \\
\text { people. }\end{array}$ & 3.3 & 0.59 & 3.2 & 0.76 & 3.76 & 0.5 & 3.6 & 0.56 \\
\hline
\end{tabular}

The table 3 indicates that experience increases after the treatment in most items, both in the experimental and control classes. However, the experimental class shows more improvements than the control class. The most salient items in the

Table 4. Learners' attitudes toward English language learning

\begin{tabular}{llllllllll}
\hline & \multicolumn{3}{l}{ Before Treatment } & \multicolumn{5}{l}{ After Treatment } \\
\hline & \multicolumn{3}{l}{$\begin{array}{l}\text { Experimental } \\
\text { class }\end{array}$} & Control class & $\begin{array}{l}\text { Experimental } \\
\text { class }\end{array}$ & Control class \\
\hline Items & Mean & $\begin{array}{l}\text { Std. } \\
\text { Dev }\end{array}$ & Mean & $\begin{array}{l}\text { Std. } \\
\text { Dev }\end{array}$ & Mean & $\begin{array}{l}\text { Std. } \\
\text { Dev }\end{array}$ & Mean & $\begin{array}{l}\text { Std. } \\
\text { Dev }\end{array}$ \\
\hline $\begin{array}{l}\text { 13. I like to learn } \\
\text { English at school. }\end{array}$ & 3.43 & 0.67 & 3.2 & 0.8 & 3.5 & 0.62 & 3.6 & 0.49 \\
$\begin{array}{l}\text { 14. I want to learn } \\
\text { English outside of school. }\end{array}$ & 3.2 & 0.55 & 2.86 & 0.81 & 3.33 & 0.71 & 2.93 & 0.9 \\
$\begin{array}{l}\text { 15. I like to do } \\
\text { English homework. }\end{array}$ & 3.9 & 0.88 & 2.93 & 0.78 & 3.13 & 0.68 & 3.3 & 0.79 \\
\hline
\end{tabular}




\begin{tabular}{|c|c|c|c|c|c|c|c|c|}
\hline \multirow[b]{3}{*}{ Items } & \multicolumn{4}{|c|}{ Before Treatment } & \multicolumn{4}{|c|}{ After Treatment } \\
\hline & \multicolumn{2}{|c|}{$\begin{array}{l}\text { Experimental } \\
\text { class }\end{array}$} & \multicolumn{2}{|c|}{ Control class } & \multicolumn{2}{|c|}{$\begin{array}{l}\text { Experimental } \\
\text { class }\end{array}$} & \multicolumn{2}{|c|}{ Control class } \\
\hline & Mean & $\begin{array}{l}\text { Std. } \\
\text { Dev }\end{array}$ & Mean & $\begin{array}{l}\text { Std. } \\
\text { Dev }\end{array}$ & Mean & $\begin{array}{l}\text { Std. } \\
\text { Dev }\end{array}$ & Mean & $\begin{array}{l}\text { Std. } \\
\text { Dev }\end{array}$ \\
\hline $\begin{array}{llr}16 . & \text { I don't } & \text { like to } \\
\text { learn } & \text { English } & \text { (mixed } \\
\text { code). } & & \end{array}$ & 1.8 & 0.66 & 1.8 & 0.88 & 1.63 & 0.71 & 1.36 & 0.55 \\
\hline $\begin{array}{l}\text { I7. I don't like to } \\
\text { look for English language } \\
\text { materials outside of } \\
\text { school (mixed code). }\end{array}$ & 2.13 & 0.73 & 2.03 & 0.88 & 1.8 & 0.8 & 2.13 & 0.93 \\
\hline $\begin{array}{l}\text { 18. I don't like to do } \\
\text { English homework (mixed } \\
\text { code). }\end{array}$ & 1.66 & 0.6 & 2 & 0.87 & 1.66 & 0.71 & 1.66 & 0.71 \\
\hline
\end{tabular}

Item 13 to 15 measure positive attitudes, while Item 16-18 measure learners' negative attitudes toward the English language. The above table indicates that the experimental class seems to be more motivated to English after the treatment (Item 13 and Item 14). Nevertheless, the experimental class seems less inclined to do English homework after the treatment as the table shows a decrease in Item 15 . The above table also shows that the control class gains a significant increase in Item 13. They are also less inclined to study English outside of school, as Item 14 experiences a decrease after the treatment. However, the control class seems to be more motivated to do English homework. In regards to negative attitudes, both classes show lesser negative attitudes after the treatment. However, the control class is shown to be less inclined to look for
English language materials outside of school.

Following are comments from respondents regarding their opinions on songs in English lessons:

"I personally think [songs] make me more motivated [to learn English] and more interested in studying during school hours. Because in my opinion, songs increase motivation as it makes [English lessons] feel more fun and the atmosphere more enjoyable." Respondent 1.

"[Learning English with songs] are very effective because when we listen to the popular songs, we can understand the words there. It's simpler than listening to the films [because it's quite long]." Respondent 2

The above comment shows that the respondents seem to find English songs to make the English more motivating 
and fun. Also, using songs can make the whole school period fun for students. The weight of evidence suggests the merits of songs in English language classrooms.

\section{Discussion}

The previous subsection indicates that the experimental class seems more motivated to learn English and show more positive attitudes than the control class after the treatment. The results also show that the experimental class is more motivated to understand English songs after the treatment. It may be attributed to songs that are integrated into their lessons during the treatment. Related to the above findings, several studies also find that songs can influence learners' motivation positively. The findings of Chen and Chen's (2009) study on the effects of English popular songs on learners' motivation and achievements suggest that the majority of students in the experimental class seem to be more motivated when songs are used in their English lessons as lesson materials. A study of Dzanic and Pejić (2016) on the effects of songs on students' motivation also suggests positive effects of songs toward students' motivation. Also, Dzanic and Pejic's (2016) study on the effects of English songs on young learners and motivation shows that young learners are more motivated to learn English and enjoy the learning process when songs are incorporated into the lessons.

Regarding the latter study, Millington (2011) confirms that songs can improve listening skills and pronunciation. Besides that, songs are useful in vocabulary teaching and sentence structures. Similarly, a study by Faliyanti (2017) on vocabulary mastery and motivation shows that the respondents seem to enjoy and obtain new vocabulary when songs are incorporated in EFL classrooms. The results of the above studies show that songs have positive effects on learners' motivation. However, despite the positive effects of songs on EFL learners' motivation, teachers need to consider several aspects before using songs in EFL classrooms. The present study's findings show that some respondents may be apprehensive about using songs in EFL classrooms because they do not understand the lyrics' words. The results of Paul's (1998) also show a similar conclusion with the point mentioned above. To minimise students' apprehension toward songs in EFL classrooms, teachers need to consider students' level of English, age, and lessons before they use certain songs in their classroom. For instance, Nadera (2015) suggests that teachers can adapt existing children's songs to suit their 
teaching contexts. Adopting the songs with the lessons will make learning more relatable to students and minimise students' apprehension. Besides, songs need to be conducted effectively by integrating the songs into meaningful classroom activities. Aiming to design a curriculum and practical activities that combine EFL learning and popular English songs, Oh (2015) proposes several activities that can boost learners' motivation and competence. Firstly, teachers can repeat the songs multiple times to get exposed to the English language to improve their pronunciation skills. Secondly, teachers can use technology such as a video maker to make videos relating to songs that they learn at school.

\section{CONCLUSION AND SUGGESTION}

Motivation is an important factor that needs to be improved to sustain learners' interests in language learning. To improve learners' motivation, teachers need to perform strategies or motivational strategies. One of the strategies that can be conducted by teachers is using songs in EFL classrooms. Thus, the present study aims to analyse the effects of songs on EFL learners' motivation. The present study uses an experimental method by dividing the respondents into two classes; experimental and control classes. While the control class was taught using a conventional method, the experimental class lessons were integrated with songs. Due to the nature of findings, quantitative data were analysed using SPSS, whereas qualitative data were coded into several categories. The findings of the present study show that songs have positive effects on EFL learners' motivation. Nevertheless, the songs need to be suited to learners' English, age, and lessons to achieve optimal results.

The present study is not without limitation. Firstly, the present study can provide more insightful results that reflect the population if conducted toward a larger number of respondents. Secondly, the present study may gain more in-depth information if it is equipped with more diverse research instruments such as classroom observation, students' journals, or teacher's journals that record teachers and students' statements after the treatment. Thirdly, the present study may gain more insights if it is conducted in a more extended period. Nevertheless, the present study still has some merits. It can be a milestone for similar studies on the effects of audiovisual materials such as songs or films on EFL learners' motivation. Further studies can compare the differences in the effects of songs and films on EFL learners' motivation. Also, a study of the differences in vocabulary 
retention of songs and films can provide deeper insights into audiovisual materials' effects. Besides that, further study can analyse the effects of songs on EFL learners' demotivation.

\section{REFERENCES}

Adara, R. A. (2019). Motivational factors to learn English among university students in an urban area. Sukma: Jurnal Pendidikan, 3(2), 187-202. https://doi.org/10.32533/03203.2019

Brown, H. D., \& Lee, H. (2015). Teaching by principles: An interactive approach to language pedagogy (4th ed.). Pearson Education.

Carrió-Pastor, M. L., \& Mestre, E. M. M. (2014). Motivation in Second Language Acquisition. Procedia Social and Behavioral Sciences, 116, 240-244.

https://doi.org/10.1016/j.sbspro.201 4.01.201

Chambers, G. N. (1999). Motivating language learners. Multilingual Matters.

Chen, Y., \& Chen, P. (2009). The effect of English popular songs on learning motivation and learning performance. WHAMPOA: An Interdisciplinary Journal, 56, 13-28.

Cheng, H.-F., \& Dörnyei, Z. (2007). The use of motivational strategies in language instruction: The case of EFL teaching in Taiwan. Innovation in Language Learning and Teaching, 1(1), 153-174. https://doi.org/10.2167/illt048.0

Coleman, H. (2011). Allocating resources for English: The case of Indonesia's
English medium International Standard Schools. In H. Coleman (Ed.), Dreams and realities: Developing countries and the English language (pp. 89-113). British Council.

Crystal, D. (2003). English as a Global Language. Cambridge University Press.

https://doi.org/10.1017/CBO978051 1486999

Dörnyei, Z. (2005). The psychology of the language learner: Individual differences in second language acquisition. Lawrence Erlbaum.

Dornyei, Z., \& Csizér, K. (2002). Some dynamics of language attitudes and motivation: Results of a longitudinal nationwide survey. Applied Linguistics, $\quad 23(4), \quad 421-462$. https://doi.org/10.1093/applin/23.4 .421

Dörnyei, Z. (2001). New themes and approaches in second language motivation research. Annual Review of Applied Linguistics, 21, 43-59. https://doi.org/10.1017/S026719050 1000034

Dörnyei, Z. (2003). Attitudes, orientations, and motivations in language learning: Advances in theory, research, and applications. Language Learning, 53(S1), 3-32. https://doi.org/10.1111/14679922.53222

Dzanic, N. D., \& Pejic, A. (2016). The effect of using songs on young learners and their motivation for learning English. NETSOL: New Trends in Social and Liberal Sciences, 1, 40-54. https://doi.org/10.24819/netsol2016 .8 
Faliyanti, E. (2017). The influence of English song toward students' vocabulary mastery and students' motivation. Premise: Journal of English Education, 6(1), $\quad$ 77-84. https://doi.org/10.24127/pj.v6i1.785

Fives, H., \& Manning, D. (2020). Teachers' strategies for student engagement: Comparing research to demonstrated knowledge. Routledge

Graddol, D. (2006). Why global English may mean the end of English as a foreign language. British Council.

Harmer, J. (2001). The practice of English language teaching. Longman.

Huang, C. (2007). Why do university students want to learn English. Taiwan Journal of TESOL, 14(1), 1-36.

Jalal, F., \& Musthafa, B. (2001). Education reform in the context of regional autonomy: The case of Indonesia. Ministry of National Education.

Karyanto, M. (2019). Peran Bahasa Indonesia dan Bahasa Inggris pada era globalisasi. https://doi.org/10.31227/osf.io/st3 u4

Khazaie, Z. M., \& Mesbah, Z. (2014). The Relationship between Extrinsic vs. Intrinsic Motivation and Strategic Use of Language of Iranian Intermediate EFL Learners. Theory and Practice in Language Studies, 4(1), 99-109.

https://doi.org/10.4304/tpls.4.1.99109

Lamb, M. V. (2007). The motivation of junior high school pupils to learn English in provincial Indonesia. School of Education, PhD Thesis (March).

Millington, N. T. (2011). Using Songs Effectively to Teach English to Young Learners. Language Education in Asia, 2(1).

https://doi.org/10.5746/leia/11/v2 Li1/a11/millington.

Nadera, B. (2015). Promoting student motivation in EFL classroom through extended music education. Procedia Social and Behavioral Sciences, 199. https://doi.org/10.1016/j.sbspro.201 5.07.520.

Oh, M. (2015). Using American pop songs in EFL classrooms (Master Thesis). University of San Fransisco.

Paul, D. (1998). Songs and games for children. Macmillan Heinemann English Language Teaching.

Poornima, B., Jayaraman, H., \& Kumar, A. A. (2016). Factors influencing Second Language Learning among urban European language learners: A sualitative study. International Journal of Indian Psychology, 3(3). https://doi.org/10.25215/0303.120

White, K. (2007). The effects of background music in the classroom on the productivity, motivation, and behavior of fourth grade students (Master Thesis). Columbia College.

Zafarghandi, A. M., \& Jodai, H. (2012). Attitudes toward English \& English learning at an Iranian Military University: A preliminary survey. https://eric.ed.gov/?id=ED528150. 